\title{
THE EFFICIENCY OF POLLUTION REMOVAL FROM DOMESTIC WASTEWATER IN CONSTRUCTED WETLAND SYSTEMS WITH VERTICAL FLOW WITH COMMON REED AND GLYCERIA MAXIMA
}

\author{
Anna Dębska' ', Krzysztof Jóźwiakowski', Magdalena Gizińska-Górna', Aneta Pytka', \\ Michał Marzec ${ }^{1}$, Bożena Sosnowska², Agata Pieńko³
}

1 Department of Environmental Engineering and Geodesy, University of Life Sciences in Lublin, Leszczyńskiego Str. 7, 20-069 Lublin, Poland, e-mail: anna.skwarzynska@up.lublin.pl, krzysztof.jozwiakowski@up.lublin.pl, madziagizinska@tlen.pl, anetapytka@poczta.fm, michał.marzec@up.lublin.pl

2 Department of Biotechnology, Human Nutrition and Food Commodities, University of Life Sciences in Lublin, Skromna Str. 8, 20-704 Lublin, Poland, e-mail: bozena.sosnowska@up.lublin.pl

3 Water and Wastewater Management Students Scientific, University of Life Sciences in Lublin, Leszczyńskiego St.r 7, 20-069 Lublin, Poland, e-mail: agatkapienko@interia.pl

Received: 2015.09 .20

Accepted: 2015.10.06

Published: 2015.11 .10

\begin{abstract}
The paper presents the results of research on the effects of removing pollution from domestic wastewater in two beds of constructed wetland systems with vertical flow. Bed I was planted with common reed (Phragmites australis Cav. Trin. Ex Steud.), whereas bed II with Glyceria maxima (Glyceria aquatica L.). The surface of each of the beds amounted to $30 \mathrm{~m}^{2}$, and the hydraulic load of each of them amounted to 0.033 $\mathrm{m}^{3} \cdot \mathrm{m}^{-2} \cdot \mathrm{d}^{-1}$. The study showed very good results in the removal of most of the analyzed indicators of contamination, which were similar in both analyzed beds. They were, respectively: 91 and $93 \%$ - for total suspended solids, 96 and $98 \%$ - for $\mathrm{BOD}_{5}, 96$ and $94 \%$ - for $\mathrm{COD}_{\mathrm{Cr}}, 88$ and $86 \%$ - for ammonia nitrogen and 87 and $88 \%$ - for total phosphorus. Much smaller effects were reported with regard to total nitrogen removal $-55 \%$ in bed I with common reed and 54\% in bed II with Glyceria maxima. The tested beds also eliminated the number of coliform bacteria and faecal coliform bacteria quite effectively. Average effects of the removal of coliform bacteria in bed I and II were $99.74 \%$, in the case of faecal coliform $98.06 \%$ and $97.94 \%$ respectively. Values of basic indicators of contamination (total suspended solids, $\mathrm{BOD}_{5}$ and $\mathrm{COD}_{\mathrm{Cr}}$ ) in the wastewater discharged from the analyzed beds met the requirements of the Regulation of the Minister of the Environment of 2014. The test results obtained in the first year of operation of the analyzed beds show that neither of the applied plants significantly improves the results of contaminant removal.
\end{abstract}

Keywords: constructed wetland, vertical flow, domestic wastewater, common reed, Glyceria maxima.

\section{INTRODUCTION}

For treating a small amount of wastewater produced in households and service facilities, located in areas without access to sewer collective, one currently uses a variety of construction systems and technology, called household sewage treatment systems [Pawęska et al. 2011]. This type of objects includes also wetlands, among which we can mention constructed wetland systems with surface sewage flow (FWS - ,free water surface") and constructed wetland systems with submerged sewage flow (VSB - ,vegetated submerged bed") [Vymazal 2008].

In recent years in Poland and around the world, constructed wetland systems are increasingly popular due to high efficiency of contaminant removal. Currently, the most commonly used 
systems are constructed wetland with vertical (VF - vertical flow) or horizontal (HF - horizontal flow) sewage flow. This type is characterized by easy and simple operation, tolerance for uneven flow of wastewater, and their construction cost is competitive, compared to using other household sewage or septic tank - "cesspool". In addition, their natural appearance enables easy integration into the existing landscape [Jóźwiakowski 2012]. Constructed wetlands systems are used for wastewater treatment throughout the year, also in winter conditions.

For many years, beds of vertical flow of wastewater are mainly used worldwide, which, thanks to favorable aerobic conditions, provide a very efficient nitrification and mineralization of organic matter. Vertical sewage flow beds in Poland are most commonly planted with common reed (Phragmites australis Cav. Trin. Ex Steud.) [Obarska-Pempkowiak et al. 2010]. In recent years there have also been attempts to use the facilities of this kind with Glyceria maxima [Jucherski, Walczowski 2012], as well as energy plants, e.g. Giant miscanthus [Gizińska et al. 2013] and other marsh plants, for example Typha, Bulrush, Iris, Sweet flag, Common club-rush [Tomczuk, Ochrymiuk 2012].

The study of Jucherski and Walczowski [2012] shows that vertical flow bed with Glyceria maxima is characterized by long-term average of wastewater treatment efficiency than a bed with common reed, also in biogenic ingredients removal. According to these authors, a vertical flow bed with Glyceria maxima provides a result of total nitrogen removal at the level of $92,9 \%$, total phosphorus $-87.4 \%$ and $\mathrm{BOD}_{5}-90.6 \%$ and $\mathrm{COD}_{\mathrm{Cr}}-87.9 \%$. These authors also found that the common reed ,due to the excessive expansion of the root, creates the danger of compaction and displacement of the beds 'minerals".
The aim of this study was to compare the results of research on the effects of pollution removal from domestic sewage in two beds of constructed wetland systems with vertical flow (VF) of common reed and Glyceria maxima in the first year of their operation.

\section{MATERIALS AND METHODS}

The study was conducted in constructed wetland wastewater treatment plant located in the village of Popkowice in the municipality of Urzędów in Lubelskie province in Poland. The first element of the analyzed object is a threechamber primary settling tank of working capacity of $8.5 \mathrm{~m}^{3}$, then the wastewater after mechanical cleaning is administered in pulses by means of a pump once a day to two parallel of constructed wetland beds: I - bed of common reed (Phragmites australis (Cav.) Trin. ex Steud.), II - bed of Glyceria maxima (Glyceria aquatica L.). Around $0.5 \mathrm{~m}^{3} \cdot \mathrm{d}^{-1}$ of wastewater flows into each of the beds, and the hydraulic load is $0.033 \mathrm{~m}^{3} \cdot \mathrm{m}^{-2} \cdot \mathrm{d}^{-1}$ each. Both beds have the same dimensions: depth $0.8 \mathrm{~m}$, length $-6 \mathrm{~m}$, width $-5 \mathrm{~m}$, and the surface of each of the beds is $30 \mathrm{~m}^{2}$ (Figure 1). Coarse sand with a diameter of $1-2 \mathrm{~mm}$ was used to fill the beds. After cleaning in the I and II bed the sewage flows into the bed of Virginia mallow with horizontal flow, and are then discharged into a drainage ditch, which flows into the Urzędówka river. In the paper we analyzed the effects of removing impurities in only two fields of the vertical flow of waste water (Figure 1).

The research was carried out in June, August and November 2014 and in January 2015. 4 series of analyzes were performed, during which 12 samples of wastewater were examined. Samples of wastewater for physico-chemical ana-

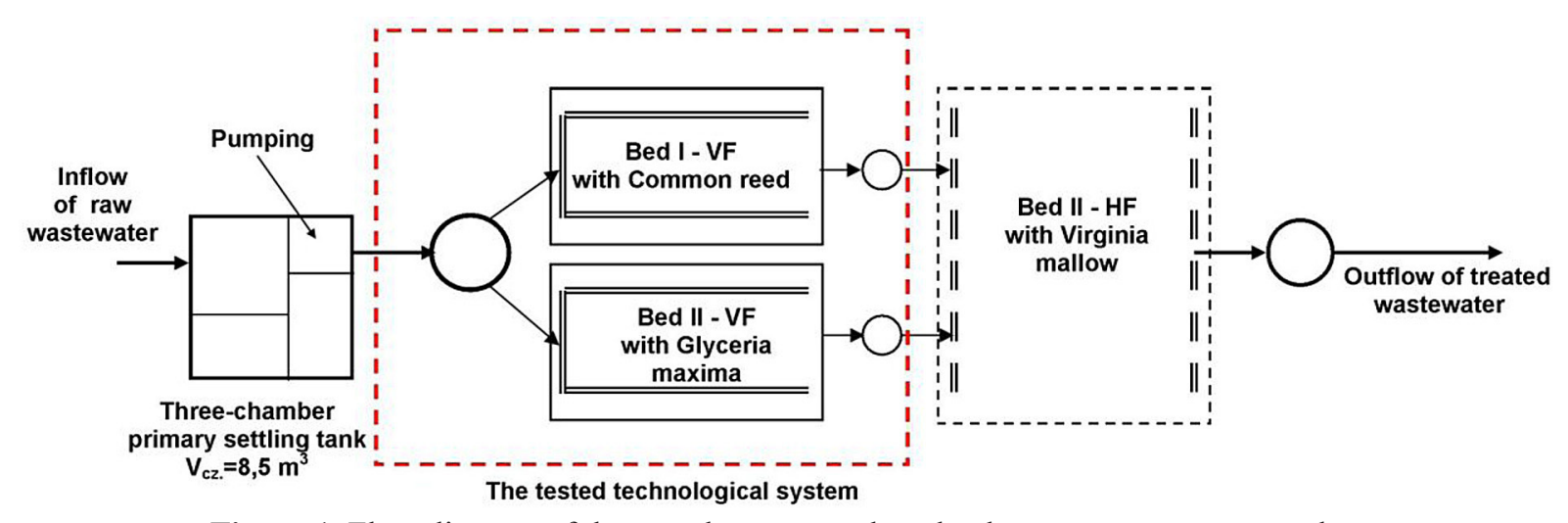

Figure 1. Flow diagram of the tested constructed wetland wastewater treatment plant 


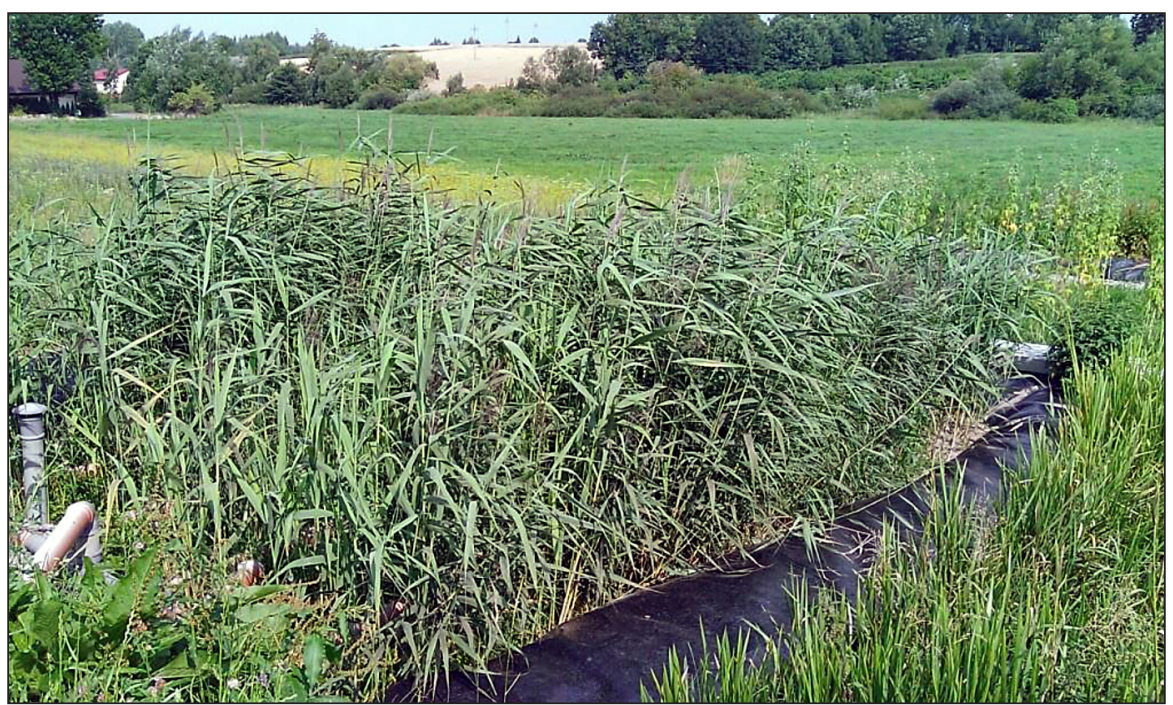

Phot. 1. Bed I with vertical flow with common reed (Phragmites australis (Cav.) Trin. ex Steud.), phot. K. Jóźwiakowski

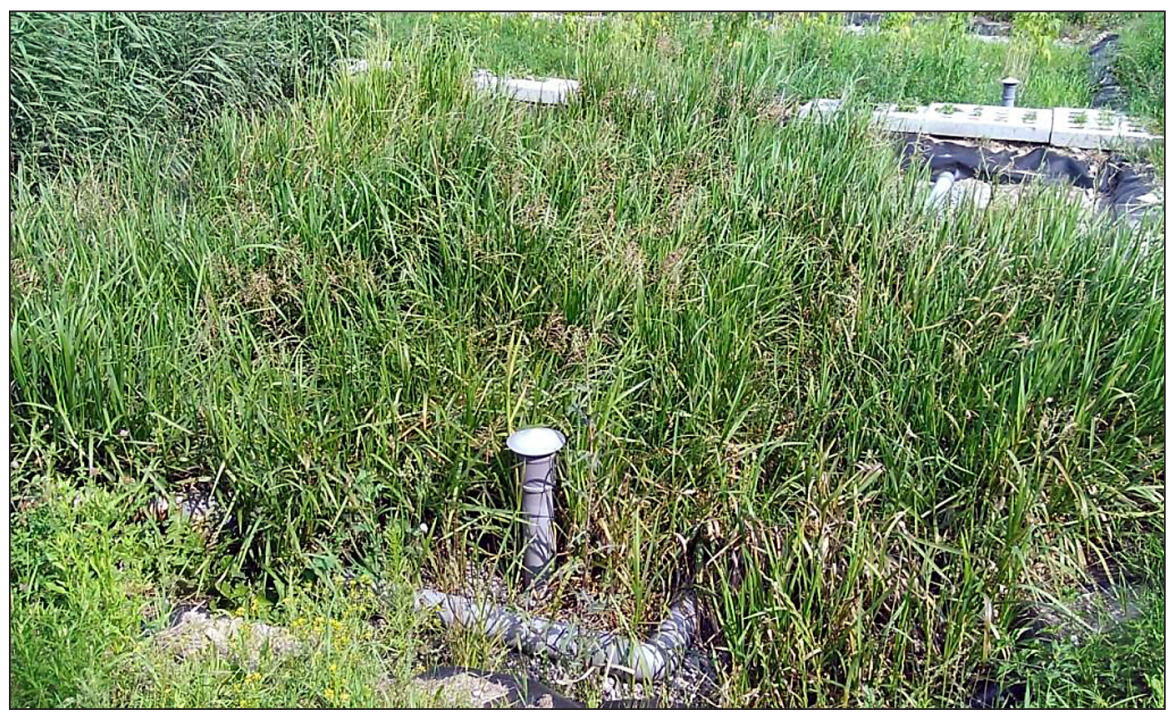

Phot. 2. Bed II with vertical flow with Glyceria maxima (Glyceria aquatica L.), phot. K. Jóźwiakowski

lyzes were collected according to the Polish norm PN-74/C-04620/00 from a pumping station - after mechanical purification and biological treatment in beds I and II. The analyzes were performed by reference methodologies of analysis of wastewater samples specified in the Regulation of the Minister of the Environment of 2014.

The sample analyzes included the determination of:

- total suspended solids - by direct gravimetric method with paper points,

- $\mathrm{BOD}_{5}$ - by dilution (oxygen content was determined using oxygen meter WTW Oxi 538),

- $\mathrm{COD}_{\mathrm{Cr}}$ - by bichromate method (COD determination was performed with WTW MPM 2010 photometer, after prior oxidation of the test sample in a thermoreactor at $148^{\circ} \mathrm{C}$ ),
- total nitrogen - with AQUALYTIC PCspectro spectrophotometer, after prior oxidation of the test sample in a thermoreactor at $100^{\circ} \mathrm{C}$,

- ammonia - with AQUALYTIC PCspectro spectrophotometer,

- total phosphorus - with WTW MPM 2010 photometer after prior oxidation of the test sample in a thermoreactor at $120^{\circ} \mathrm{C}$.

The study also collected wastewater samples for microbiological analysis. The number of $\mathrm{CO}^{-}$ liform bacteria and faecal coliform bacteria was determined in the collected samples. Microbiological testing was performed by Polish standards (PN-C-04615-05:1975P, PN-C-0461507:1977P). The minimum, maximum, mean and standard deviation were identified based on the 
results of studies (Table 1). The efficiency of removing impurities in the analyzed beds was determined on the basis of the average values of the analyzed indicators of contamination in wastewater flowing in $\left(\mathrm{C}_{\mathrm{d}}\right)$ and out $\left(\mathrm{C}_{\mathrm{o}}\right)$ of the beds according to formula 1 :

$$
\mathrm{D}=\left(1-\mathrm{C}_{\mathrm{o}} / \mathrm{C}_{\mathrm{d}}\right) \times 100, \%
$$

The results were compared with the requirements of the Regulation of the Minister of Environment from 2014.

\section{RESULTS AND DISCUSSION}

The study showed very good results in the removal of the analyzed indicators of contamination, which were similar in both analyzed beds of constructed wetland. Table 1 shows physical and chemical composition of the wastewater treated in the studied beds, and Figure 2 shows the average efficiency of wastewater treatment. Table 2 and Figure 3 show the number of coliform bacteria and faecal coliform bacteria in the studied wastewater and the effects of their removal.

\section{Total suspended solids}

The average removal efficiency of total suspended solids in the studied constructed wetland systems was comparable: $91.2 \%$ in bed I with common reed and $93.0 \%$ in bed II with Glyceria maxima (Figure 2). It was found that the concentration of total suspended solids in wastewater flowing from bed I ranged from 12.00 to $47.00 \mathrm{mg} \cdot \mathrm{dm}^{-3}$, and the average was 27.50 $\mathrm{mg} \cdot \mathrm{dm}^{-3}$. In contrast, in the wastewater discharged from bed II the concentration of total suspended solids ranged from 10.80 to $30.00 \mathrm{mg} \cdot \mathrm{dm}^{-3}$, and the average was $21.70 \mathrm{mg} \cdot \mathrm{dm}^{-3}$ (Table 1 ). Average concentrations of total suspended solids in the treated wastewater discharged from the tested beds were lower than the limit value $\left(50 \mathrm{mg} \cdot \mathrm{dm}^{-3}\right)$ defined in the Regulation [2014].

Table 1. Physical and chemical composition of the wastewater treated in tested constructed wetland systems with vertical flow with common reed and Glyceria maxima

\begin{tabular}{|c|c|c|c|c|}
\hline \multicolumn{2}{|l|}{ Parameters } & $\begin{array}{l}\text { Wastewater after the } \\
\text { mechanical treatment }\end{array}$ & $\begin{array}{l}\text { Wastewater after bed I } \\
\text { with common reed }\end{array}$ & $\begin{array}{l}\text { Wastewater after bed II } \\
\text { with Glyceria maxima }\end{array}$ \\
\hline \multirow{4}{*}{$\begin{array}{l}\text { Total suspended solids } \\
\qquad\left[\mathrm{mg}^{-} \cdot \mathrm{dm}^{-3}\right]\end{array}$} & $\min$ & 82.00 & 12.00 & 10.80 \\
\hline & $\max$ & 229.00 & 47.00 & 30.00 \\
\hline & $x$ & 142.25 & 27.50 & 21.70 \\
\hline & $\sigma$ & 62.37 & 14.53 & 7.98 \\
\hline \multirow{4}{*}{$\begin{array}{c}\mathrm{BOD}_{5} \\
{\left[\mathrm{mg} \mathrm{O}_{2} \cdot \mathrm{dm}^{-3}\right]}\end{array}$} & $\min$ & 286.50 & 4.30 & 2.35 \\
\hline & $\max$ & 637.00 & 55.20 & 20.40 \\
\hline & $x$ & 420.75 & 17.80 & 8.54 \\
\hline & $\sigma$ & 159.06 & 24.95 & 8.42 \\
\hline \multirow{4}{*}{$\begin{array}{c}\mathrm{COD}_{\mathrm{Cr}} \\
{\left[\mathrm{mg} \mathrm{O}_{2} \cdot \mathrm{dm}^{-3}\right]}\end{array}$} & $\min$ & 420.00 & 13.00 & 12.00 \\
\hline & $\max$ & 1366.00 & 97.00 & 160.00 \\
\hline & $x$ & 759.00 & 37.75 & 52.50 \\
\hline & $\sigma$ & 417.03 & 40.01 & 71.91 \\
\hline \multirow{4}{*}{ 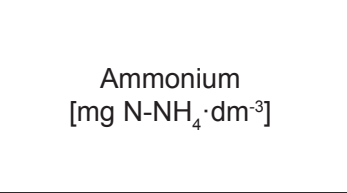 } & $\min$ & 29.00 & 0.83 & 0.36 \\
\hline & $\max$ & 114.00 & 16.60 & 14.70 \\
\hline & $x$ & 68.50 & 9.41 & 10.50 \\
\hline & $\sigma$ & 35.73 & 6.91 & 6.79 \\
\hline \multirow{4}{*}{$\begin{array}{l}\text { Total nitrogen } \\
{\left[\mathrm{mg}^{\left.-\mathrm{dm}^{-3}\right]}\right.}\end{array}$} & $\min$ & 38.00 & 34.00 & 25.00 \\
\hline & $\max$ & 115.00 & 55.00 & 64.00 \\
\hline & $x$ & 77.00 & 42.00 & 43.75 \\
\hline & $\sigma$ & 35.24 & 9.13 & 16.68 \\
\hline \multirow{4}{*}{ Total phosphorus $\left[\mathrm{mg} \cdot \mathrm{dm}^{-3}\right]$} & $\min$ & 4.70 & 0.63 & 0.40 \\
\hline & $\max$ & 38.00 & 5.32 & 4.61 \\
\hline & $x$ & 17.35 & 2.41 & 2.11 \\
\hline & $\sigma$ & 14.59 & 2.23 & 1.99 \\
\hline
\end{tabular}

Comments: $\min$ - minimum value, $\max$ - maximum value, $x$ - average value, $\sigma-$ standard deviation. 


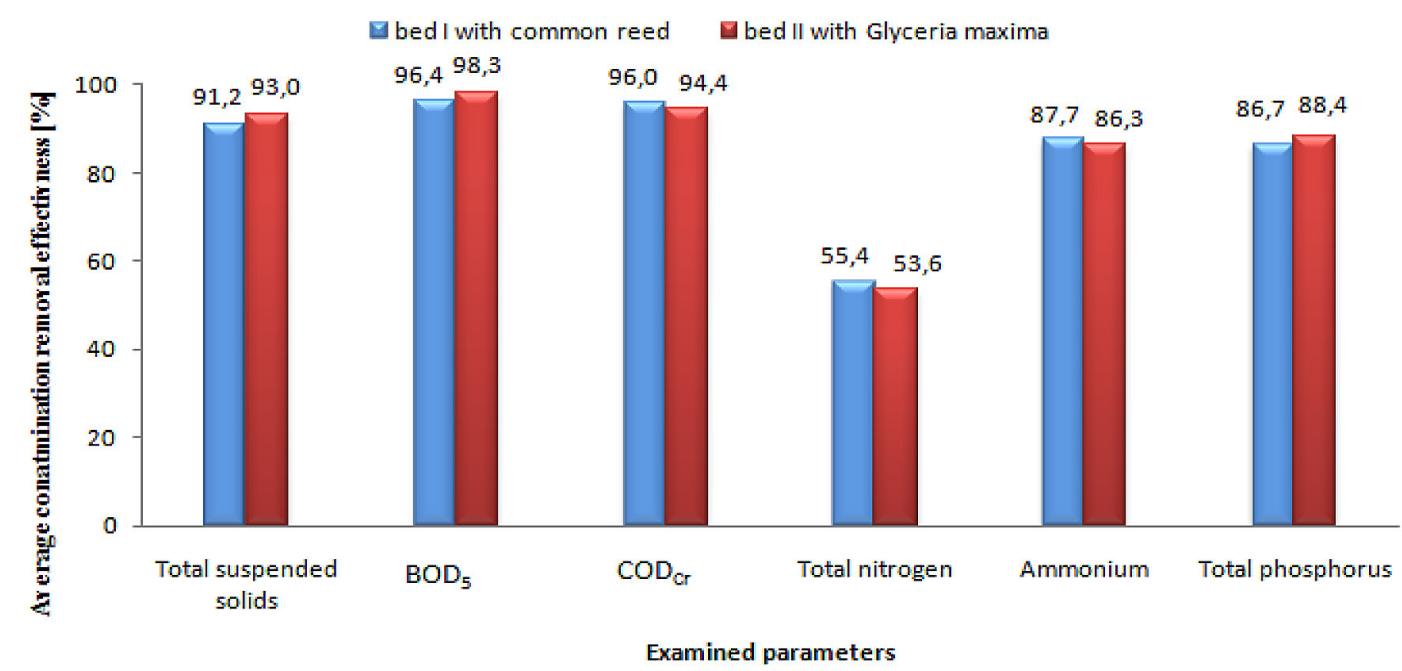

Figure 2. Average contamination removal efficiency in tested constructed wetland systems with vertical flow with common reed and Glyceria maxima

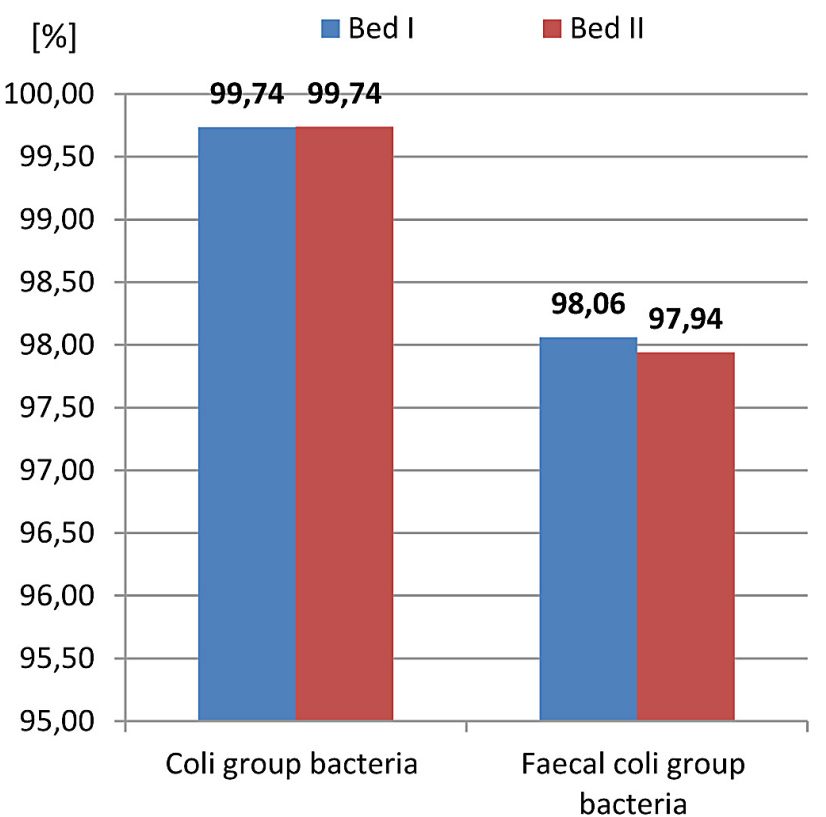

Figure 3. The average removal efficiency of microbial contamination in the tested constructed wetland systems with vertical flow with common reed and Glyceria maxima

In studies by Gizińska et al. [2013] the total suspended solids removal efficiency in the bed with vertical flow with common reed was lower than in the studied beds and was $78 \%$, and the average concentration of total suspended solids was $24 \mathrm{mg} \cdot \mathrm{dm}^{-3}$. Past experience indicates worldwide that total suspended solids removal efficiency in systems with vertical flow with common reed ranges from $65-90 \%$ [Hablerl et al. 1995; Chen et al. 2008; Vymazal 2010; Jóźwiakowski 2012]. The total suspended solids removal efficiency in the studied beds is slightly higher than that obtained in the similar objects around the world.
$\mathrm{BOD}_{5}$

The study showed a very high efficiency of wastewater treatment of organic matter. In bed I with common reed the average efficiency of the elimination of $\mathrm{BOD}_{5}$ was $96.4 \%$, and in bed II with Glyceria maxima $98.3 \%$ (Figure 2). It was found that the value of $\mathrm{BOD}_{5}$ in the wastewater flowing from bed I ranged from 4.30 to $55.20 \mathrm{mg}$ $\mathrm{O}_{2} \cdot \mathrm{dm}^{-3}$ and the average was $17.80 \mathrm{mg} \mathrm{O} \cdot \mathrm{dm}^{-3}$. However, in the wastewater discharged from bed II the $\mathrm{BOD}_{5}$ value ranged from 2.35 to $20.40 \mathrm{mg}$ $\mathrm{O}_{2} \cdot \mathrm{dm}^{-3}$, and the average was $8.54 \mathrm{mg} \mathrm{O} \cdot \mathrm{dm}^{-3}$ (Table 1). The average values of $\mathrm{BOD}_{5}$ in treated 
Table 2. Numbers of coliform bacteria and of faecal coliform bacteria in wastewater treated in the tested constructed wetland systems with vertical flow with common reed and Glyceria maxima

\begin{tabular}{|c|c|c|c|}
\hline Investigated microbiological indicators & Kind of sewage & Range & Mean \\
\hline \multirow{3}{*}{$\begin{array}{l}\text { Mean numbers of coliform bacteria } \\
\text { in } \mathrm{MPN} \times 100 \mathrm{~cm}^{-3} \text { (incubation at } 37^{\circ} \mathrm{C} \text { ) }\end{array}$} & Outflow from septic tank & $7.0 \times 10^{5}-7.0 \times 10^{8}$ & $2.5 \times 10^{8}$ \\
\hline & Outflow from bed I & $2.0 \times 10^{3}-2.4 \times 10^{6}$ & $6.6 \times 10^{5}$ \\
\hline & Outflow from bed II & $5.0 \times 10^{2}-2.4 \times 10^{6}$ & $6.6 \times 10^{5}$ \\
\hline \multirow{3}{*}{$\begin{array}{l}\text { Numbers of faecal coliform bacteria } \\
\text { in } \mathrm{MPN} \times 100 \mathrm{~cm}^{-3} \text { (incubation at } 44^{\circ} \mathrm{C} \text { ) }\end{array}$} & Outflow from septic tank & $2.3 \times 10^{5}-2.4 \times 10^{7}$ & $9.4 \times 10^{6}$ \\
\hline & Outflow from bed I & $6.2 \times 10^{2}-7.0 \times 10^{5}$ & $1.8 \times 10^{5}$ \\
\hline & Outflow from bed II & $2.4 \times 10^{2}-7.0 \times 10^{5}$ & $1.9 \times 10^{5}$ \\
\hline
\end{tabular}

wastewater discharged from the tested beds were lower than the limit value $\left(40 \mathrm{mg} \mathrm{O}_{2} \cdot \mathrm{dm}^{-3}\right)$ defined in the Regulation [2014]. Only the maximum value obtained in the wastewater discharged from bed I with common reed $\left(55.20 \mathrm{mg} \mathrm{O}_{2} \cdot \mathrm{dm}^{-3}\right)$ was higher than the limit value defined in the above mentioned regulation.

Research carried out by Gizińska et al. [2013] shows that the efficiency of $\mathrm{BOD}_{5}$ removal from wastewater in a bed of vertical flow with common reed was similar to that obtained in the examined beds and amounted to $97 \%$, and the average $\mathrm{BOD}_{5}$ value in the bed outflow amounted to $14.2 \mathrm{mg} \mathrm{O}_{2} \cdot \mathrm{dm}^{-3}$.

The efficiency of the tested object was significantly higher, than that found by Jucherski and Walczowski [2012] in slope constructed wetland beds with common reed and Glyceria maxima. These authors' studies show that the effectiveness of the elimination of $\mathrm{BOD}_{5}$ in the bed with vertical flow with common reed was $59.7 \%$, and in bed with Glyceria maxima $60.8 \%$.

Past experience indicates worldwide, that the $\mathrm{BOD}_{5}$ efficiency reduction in vertical flow systems with common reed ranges from 84 to $96 \%$ [Haberl et al. 1995; Chen et al. 2008; Vymazal 2010; Jóźwiakowski 2012].

\section{$\operatorname{COD}_{\mathrm{Cr}}$}

In bed I with common reed the efficiency of $\mathrm{COD}_{\mathrm{Cr}}$ removal was $96,0 \%$, and in bed II with Glyceria maxima 94,4\% (Figure 2). It was found that the $\mathrm{COD}_{\mathrm{Cr}}$ value in the wastewater flowing from bed I ranged from 13.00 to $97.00 \mathrm{mg} \mathrm{O}_{2} \cdot \mathrm{dm}^{-3}$, and the average was $37.75 \mathrm{mg} \mathrm{O}_{2} \cdot \mathrm{dm}^{-3}$. And in the wastewater flowing from bed II the $\mathrm{COD}_{\mathrm{Cr}}$ value ranged from 12.00 to $160.00 \mathrm{mg} \mathrm{O}_{2} \cdot \mathrm{dm}^{-3}$, and the average was $52.50 \mathrm{mg} \mathrm{O}_{2} \cdot \mathrm{dm}^{-3}$ (Table 1).

The average $\mathrm{COD}_{\mathrm{Cr}}$ values in the treated wastewater discharged from the studied beds were lower than limit value $\left(150 \mathrm{mg} \mathrm{O} \cdot \mathrm{dm}^{-3}\right)$ defined in Regulation of the Minister of the Environment of 2014. Only the maximum value obtained in the wastewater discharged from bed II with Glyceria maxima (160.00 $\mathrm{mg} \mathrm{O}_{2} \cdot \mathrm{dm}^{-3}$ ) was lower than the limit value defined in the Regulation [2014].

Research carried out by Gizińska et al. [2013] shows, that the efficiency of removal of $\mathrm{COD}_{\mathrm{Cr}}$ from wastewater in a bed of vertical flow with common reed was similar to that obtained in the examined beds and amounted to $95 \%$, and the average $\mathrm{COD}_{\mathrm{Cr}}$ value in the discharged wastewater was $31.5 \mathrm{mg} \mathrm{O} \cdot \mathrm{dm}^{-3}$.

In similar facilities worldwide, there was not so high $\mathrm{COD}_{\mathrm{Cr}}$ lowering effects. In systems with vertical flow of common reed $\mathrm{COD}_{\mathrm{Cr}}$ reduction effectiveness ranged from 78 to $82 \%$ [Haberl et al. 1995; Chen et al. 2008; Jóźwiakowski 2012]. Also, in a study conducted by Tomczuk i Ochrymiuk [2012] and Ávila [2015] the effectiveness of removal of organic compounds expressed by the $\mathrm{COD}_{\mathrm{Cr}}$ was $83 \%$.

\section{Ammonium}

In the studied beds, there were found very high effects of ammonium nitrogen removal - on average $87.7 \%$ - in bed I with common reed and $86.3 \%$ - in bed II with Glyceria maxima (Figure 2). The content of ammonia nitrogen in the wastewater discharged from the bed with common reed ranged from $0.83-16.60 \mathrm{mg} \mathrm{N}-\mathrm{NH}_{4} \cdot \mathrm{dm}^{-3}$, and the average was $9.41 \mathrm{~N}-\mathrm{NH}_{4} \cdot \mathrm{dm}^{-3}$. In the wastewater discharged from bed with Glyceria maxima ranged from 0.36 to $14.70 \mathrm{mg}$ $\mathrm{N}-\mathrm{NH}_{4} \cdot \mathrm{dm}^{-3}$ and the average was $10.50 \mathrm{~N}-\mathrm{NH}_{4} \cdot \mathrm{dm}^{-3}$.

Based on the study by Tomczuk and Ochrymiuk [2012] in a bed with vertical wastewater flow it was determined, that the average ammonium removal effectiveness was $78 \%$. And the study carried out by Gizińska et al. [2013] showed, that ammonium removal effectiveness from wastewa- 
ter in the bed with vertical flow with common reed was significantly higher in the examined beds and amounted to $98 \%$, and the average concentration of ammonium nitrogen was $13.9 \mathrm{mg} \mathrm{N}-\mathrm{NH}_{4} \cdot \mathrm{dm}^{-3}$. High effectiveness of ammonia nitrogen removal in VF type deposits VF are the evidence of a good bed oxygenation, which allows for a proper conduct of nitrification.

\section{Total nitrogen}

The average effectiveness of total nitrogen removal in the examined constructed wetland beds was similar and amounted to $55.4 \%$ in bed I with common reed and $53.6 \%$ in bed II with Glyceria maxima (Figure 2). The concentration of total nitrogen in the effluent from bed I ranged from 34.00 to $55.00 \mathrm{mg} \cdot \mathrm{dm}^{-3}$, and the average was $42.00 \mathrm{mg} \cdot \mathrm{dm}^{-3}$. And in the effluent from bed II the total nitrogen concentration ranged from 25.00 to $64.00 \mathrm{mg} \cdot \mathrm{dm}^{-3}$, and the average was 43.75 $\mathrm{mg} \cdot \mathrm{dm}^{-3}$ (Table 1).

The Regulation [2014] defines (with Equivalent Number of Residents under 2000) the maximum concentration of total nitrogen -30 $\mathrm{mg} \cdot \mathrm{dm}^{-3}$, but only in the case of discharging sewage into lakes and their tributaries and directly to reservoirs located on the flowing waters. For the object analyzed in this work such requirements were not specified.

Research carried out by Gizińska et al. [2013] shows, that total nitrogen removal effectiveness from wastewater in the bed with vertical flow with common reed was lower than in the examined beds and amounted to $29.5 \%$, and the average concentration of total nitrogen in the effluent was $73 \mathrm{mg} \cdot \mathrm{dm}^{-3}$. Significantly better results of total nitrogen removal, than in the examined facility, were found by Jucherski and Walczowski in beds with common reed and Glyceria maxima [2012]. According to these authors, removal efficiency of total nitrogen in the bed of vertical flow of wastewater with common reed was $75 \%$, while in the bed of Glyceria maxima it was significantly higher and amounted to $93 \%$.

Past experience indicates that the removal efficiency of total nitrogen in vertical flow systems with common reed ranges from 24 to $43 \%$ [Hablerl et al. 1995; Vymazal et al. 2010; Jóźwiakowski 2012]. Total nitrogen removal efficiency in the studied beds is much higher than that achieved in similar establishments in the world.

Experience shows that the effectiveness of the overall nitrogen removal in the beds of verti- cal flow of wastewater does not give satisfactory results, because such objects provide only nitrification process, i.e. the conversion of ammonium to nitrate nitrogen [Luederitz et al. 2001]. In such systems, there is generally no denitrification, which makes it possible to remove total nitrogen in a much greater extent. It was shown that favorable conditions for the decomposition of organic matter and for denitrification is provided by beds with a horizontal flow of effluent (HF) [ObarskaPempkowiak et al. 2010, Jóźwiakowski 2012]

In order to enhance the effects of removing contamination in recent years hybrid systems are more and more popular They consist of two or three VF and HF type beds which provide better conditions for biological treatment of wastewater [Obarska-Pempkowiak, Gajewska 2005, Jóźwiakowski 2012].

\section{Total phosphorus}

The average total phosphorus removal efficiency in the studied constructed wetland beds was similar and amounted to $86,7 \%$ in bed I with common reed and $88.4 \%$ in bed II with Glyceria maxima (Figure 2). The concentration of phosphorus in the effluent flowing from bed I ranged from 0.63 to $5.32 \mathrm{mg} \cdot \mathrm{dm}^{-3}$ and the average was $2.41 \mathrm{mg} \cdot \mathrm{dm}^{-3}$. And in the effluent flowing from bed II the concentration of total phosphorus ranged from 0.40 to $4.61 \mathrm{mg} \cdot \mathrm{dm}^{-3}$, and the average was $2.11 \mathrm{mg} \cdot \mathrm{dm}^{-3}$ (Tabela 1$)$. The Regulation [2014] defines (as in the case of total nitrogen) maximum permissible value of total phosphorus only in the case of discharging sewage into lakes and their tributaries and directly to reservoirs located on the flowing waters, which is $5 \mathrm{mg} \cdot \mathrm{dm}^{-3}$. For an object analyzed in this work such requirements were not specified.

In the research carried out by Gizińska et al. [2013] total phosphorus removal effectiveness from wastewater in the bed with vertical flow with common reed was lower than in the examined beds and amounted to $68 \%$, and the average total phosphorus concentration was 9,8 $\mathrm{mg} \cdot \mathrm{dm}^{-3}$. Studies by Jucherski and Walczowski [2012] showed that the effectiveness of a vertical flow bed with Glyceria maxima (87\%) in removing total phosphorus was significantly higher than the bed with common reed (58\%).

Past experience indicates that the removal efficiency of total phosphorus in vertical flow systems with common reed ranges from 43-99\% [Hablerl et al. 1995; Chen et al. 2008; Vymazal 
2010; Jóźwiakowski 2012]. However, a study by Warężak et al. [2013] shows that the removal efficiency of total phosphorus in vertical flow systems ranges from 55 to $84 \%$.

\section{Microbiological factors}

The study shows that the sewage flowing into the analyzed constructed wetland beds contained very large numbers of coliform bacteria $\left(2.5 \cdot 10^{8}\right.$ MPN.100 $\mathrm{cm}^{-3}$ ) and faecal coliform bacteria $\left(9.4 \cdot 10^{6} \mathrm{MPN} \cdot 100 \mathrm{~cm}^{-3}\right.$ ) (Table 2). Slightly lower numbers of coliform bacteria $\left(8.3 \cdot 10^{6}\right.$ to $1.4 \cdot 10^{7}$ MPN $\cdot 100 \mathrm{~cm}^{-3}$ ) and faecal coliform bacteria $\left(2.1 \cdot 10^{6}\right.$ to $\left.3.3 \cdot 10^{6} \mathrm{MPN} \cdot 100 \mathrm{~cm}^{-3}\right)$ were recorded in the wastewater fed to other constructed wetland facilities with reed and willow [Jóźwiakowski et al. 2009; Jóźwiakowski 2012]. On the other hand, in the wastewater flowing into the soil cane filter in the municipal sewage treatment plant in Wielka Nieszawka, in Torun county, the number of coliform bacteria ranged from $4.3 \cdot 10^{4}$ to $4.3 \cdot 10^{5}$ MPN $\cdot 100 \mathrm{~cm}^{-3}$, and faecal coliform bacteria from $3.0 \cdot 10^{3}$ to $3.9 \cdot 10^{4} \mathrm{MPN} \cdot 100 \mathrm{~cm}^{-3}$ [Lalke-Porczyk et al. 2010].

Based on the results presented in table 2, the average effects of removal of coliform bacteria and faecal coliform bacteria in the analyzed beds were calculated (Figure 3). The obtained data shows that both examined beds are highly effective in removal of coliform bacteria (99.74\%) and less effective in elimination of faecal coliform (97.94-98.06\%). Similar effects of elimination of the analyzed bacteria groups (98.09-99.88\%) were reported in VF and HF constructed wetland bed types with reed and willow in the Lublin province in Poland [Jóźwiakowski et al. 2009; Jóźwiakowski 2012] and in a reed bed in England (96,6-98,9\%) [Decamp, Warren 2000]. While in Tanzania in systems of that type with reed and typha the effects of the elimination of coliform bacteria and faecal coliform bacteria were only $43-72 \%$ [Kaseva 2004]. In contrast, other studies carried out by Lalke-Porczyk et al. [2010] in beds of reeds and willow near Torun in Poland showed an average elimination of coliform bacteria and faecal coliform bacteria at the level of $94.51-94.71 \%$ and $92.07-94.95 \%$ respectively.

It was found that the number of coliform bacteria in sewage flowing out of the surveyed beds no. I and II was on average $6.6 \cdot 10^{5} \mathrm{MPN} \cdot 100 \mathrm{~cm}^{-3}$, and the number of faecal coliform bacteria was $1.8 \cdot 10^{5}$ and $1.9 \cdot 10^{5}$ MPN $\cdot 100 \mathrm{~cm}^{-3}$ respectively and despite the high efficiency of their removal remained high. Significantly lower numbers of these indicator bacteria $\left(8.2 \cdot 10^{3}-8.1 \cdot 10^{4} \mathrm{MPN}\right.$ $\cdot 100 \mathrm{~cm}^{-3}$ ) were recorded in the wastewater discharged from constructed wetland beds of VF and HF type with reed and willow in Lublin province in Poland after several years of operation [Jóźwiakowski et al. 2009; Jóźwiakowski 2012]. And in wastewater flowing from constructed wetland beds with reed and willow near Torun the number of coliform bacteria ranged from 1.0 $10^{2}$ to $1.2 \cdot 10^{4} \mathrm{MPN} \cdot 100 \mathrm{~cm}^{-3}$ and of faecal coliform bacteria from $1.0 \cdot 10^{1}$ to $1.0 \cdot 10^{3} \mathrm{MPN} \cdot 100 \mathrm{~cm}^{-3}$ [Lalke-Porczyk et al. 2010].

\section{CONCLUSIONS}

1. Both studies constructed wetland beds with vertical flow with common reed and Glyceria maxima provided very good results in removing pollutants from domestic sewage.

2. The effectiveness of removing pollution in bed I and II was 91.2 and $93.0 \%$ respectively - for total suspended solids, 96.4 and $98.3 \%$ - for $\mathrm{BOD}_{5}, 96.0$ and $94.4 \%$ - for $\mathrm{COD}_{\mathrm{Cr}}, 87.7$ and $86.3 \%$ - for ammonium and 86.7 and $88.4 \%$ - for total phosphorus. Only the average total nitrogen removal efficiency in the studied beds was lower and amounted to $55.4 \%$ in bed I with common reed and $53.6 \%$ in bed II with Glyceria maxima.

3. It was found that the efficiency of removing microbiological indicators in bed I and II was on average $99.74 \%$ - in the case of coliform bacteria and 98.06 and $97.94 \%$ respectively in the case of faecal coliform.

4. Concentrations of basic indicators of pollution (TSS, $\mathrm{BOD}_{5}$ and $\mathrm{COD}_{\mathrm{Cr}}$ ) in the wastewater discharged from the analyzed beds meet the requirements defined in the Regulation [2014].

\section{REFERENCES}

1. Ávila C., Bayona J., Martín I., Salasc J., García J. 2015. Emerging organic contaminant removal in a full-scale hybrid constructed wetland system for wastewater treatment and reuse. Ecological Engineering, 7, 108-116.

2. Chen Z.M., Chen B., Zhou J.B., Li Z., Zhou Y., Xi X.R., Lin C., Chen G.Q. 2008. A vertical subsurface - flow constructed wetland in Beijing. Communications in Nonlinear Science and Numerical Simulation, 13(9), 1986-1997. 
3. Decamp O., Warren A. 2000. Investigation of Escherichia coli removal in various designs of subsurface flow wetlands used for wastewater treatment. Ecological Engineering, 14(3), 293-299.

4. Gizińska M., Jóźwiakowski K., Pytka A., Marzec M. 2013. Wstępne badania nad skutecznością usuwania zanieczyszczeń w 4-stopniowej hybrydowej oczyszczalni gruntowo-roślinnej. Gaz, Woda i Technika Sanitarna, 2, 47-50.

5. Haberl R., Perfler R., Mayer H. 1995. Constructed wetlands in Europe. Water Science and Technology, 32(3), 305-315.

6. Jucherski A., Walczowski A. 2012. Wpływ wybranych makrofitów na skuteczność oczyszczania ścieków w stokowych złożach filtracyjnych gruntowo-roślinnych. Problemy Inżynierii Rolniczej, 20(1), 115-124.

7. Jóźwiakowski K., Korniłłowicz-Kowalska T., Iglik H. 2009. Estimation of sanitary status of sewage treated in constructed wetland systems. Sewage and waste materials in environment. Monograph. W. Sądej (Ed.) Contemporary problems of management and environmental protection. University of Warmia and Mazury in Olsztyn, Chapter $1,7-21$.

8. Jóźwiakowski K. 2012. Badania skuteczności oczyszczania ścieków w wybranych systemach gruntowo-roślinnych. Monografia. Rozprawa habilitacyjna. Infrastruktura i ekologia terenów wiejskich. PAN Oddział w Krakowie. Komisja Technicznej Infrastruktury Wsi, 1, 230.

9. Kaseva M.E. 2004. Performance of a sub-surface flow constructed wetland in polishing pre-treated wastewater - a tropical case study. Water Research 38, 681-687.

10. Lalke-Porczyk E., Swiontek-Brzezinska M., Donderski W. 2010. Rola oczyszczalni hydrobotanicznych w oczyszczaniu ścieków $\mathrm{z}$ terenów wiejskich. Woda-Środowisko-Obszary Wiejskie, t. 10, z. 3(31), 119-127.

11. Luederitz V., Eckert E., Lange-Weber M., Lange A., Gersberg R.M. 2001. Nutrient removal efficiency and resource economics of vertical flow and horizontal flow constructed wet-lands. Ecological Engineering, 18, 157-171.

12. Obarska-Pempkowiak H., Gajewska M. 2005. Operation of multistage constructed wetlands systems in remporary climate. International Symposium on Water Management and Hydraulic Engineering. Ottenstein/ Austria, 4-7.IX.2005, Paper No: VI.05.

13. Obarska-Pempkowiak H., Gajewska M., Wojciechowska E. 2010. Hydrofitowe oczyszczanie wód i ścieków. Wydawnictwo Naukowe PWN, 35-40.

14. Pawęska K., Pulikowski K., Strzelczyk M., Rajmund A. 2011. Osadnik gnilny - podstawowy element przydomowej oczyszczalni ścieków. Infrastruktura i Ekologia Terenów Wiejskich, 10, 43-53.

15. PN-74/C-04620/00 Woda i ścieki. Pobieranie próbek. Postanowienia ogólne i zakres normy.

16. PN-C-04615-05:1975P. Woda i ścieki. Badania mikrobiologiczne. Oznaczanie bakterii grupy coli metodą fermentacyjną probówkową.

17. PN-C-04615-07:1977P. Woda i ścieki. Badania mikrobiologiczne. Oznaczanie bakterii grupy coli typu kałowego (fekalnego) metodą fermentacyjną probówkową.

18. Rozporządzenie Ministra Środowiska z dnia 18 listopada 2014 r. w sprawie warunków, jakie należy spełnić przy wprowadzaniu ścieków do wód lub do ziemi oraz w sprawie substancji szczególnie szkodliwych dla środowiska wodnego.

19. Tomczuk B., Ochrymiuk D. 2012. Ocena efektywności gruntowo-roślinnych oczyszczalni ścieków na podstawie wyników rocznego projektu badawczego. Inżynieria Ekologiczna, 28, 57-67.

20. Warężak T., Sadecka Z., Myszograj S., Suchowska-Kisielewicz M., 2013. Skuteczność oczyszczania ścieków w oczyszczalni hydrofitowej typu VF-CW. Rocznik Ochrona Środowiska, 15, 1243-1259.

21. Vymazal J. 2008. Constructed wetlands for wastewater treatment: A review. In: Sengupta M. and Dalwani, R. (Eds). Proceedings of Taal 2007: The $12^{\text {th }}$ World Lake Conference, 965-980.

22. Vymazal J. 2010. Constructed Wetlands for Wastewater Treatment. Water 2 (3), 530-549.

Pracę dofinansowano ze środków Wojewódzkiego Funduszu Ochrony Środowiska i Gospodarki Wodnej w Lublinie. 